\title{
LOCALIZATION OF PMP-22 GENE (CANDIDATE GENE FOR THE CHARCOT-MARIE-TOOTH DISEASE 1A) TO BAND 17p11.2 BY DIRECT R-BANDING FLUORESCENCE IN SITU HYBRIDIZATION
}

\author{
Ei-ichi Takahashi, ${ }^{1}$ Osamu Takeda, ${ }^{2}$ Masato Himoro, ${ }^{3}$ \\ Kenji NanaO, ${ }^{3}$ Goro TaKada, ${ }^{3}$ and Kiyoshi HayasaKa ${ }^{3, *}$ \\ ${ }^{1}$ Division of Genetics, National Institute of Radiological Science, \\ Anagawa, Inage-ku, Chiba 263, Japan \\ ${ }^{2}$ Biotechnology Research Laboratories, Takara Shuzo Co., Ltd., Otsu, Shiga 520-21, Japan \\ ${ }^{3}$ Department of Pediatrics and Dentistry, Akita University School of Medicine, \\ Hondo, Akita 010, Japan
}

\begin{abstract}
Summary We mapped PMP-22 gene, candidate gene for the CharcotMarie-Tooth disease (CMT) 1A, by direct R-banding fluorescence in situ hybridization. The signals of PMP-22 probe were localized to chromosome band $17 \mathrm{pl1.2}$. The present result was within the map position of the CMT 1A gene by genetic linkage analysis, and strongly indicated that PMP-22 gene is a candidate gene for the CMT $1 \mathrm{~A}$.

Key Words mapping of PMP-22 gene, direct R-banding FISH, 17p11.2
\end{abstract}

\section{INTRODUCTION}

Myelin is a multilamellar compacted membrane structure that surrounds and insulates the axon, facilitating the conduction of nerve impulses. Schwann cells are responsible for myelin formation in the peripheral nervous system. P0, P2, myelin basic protein (MBP) and myelin associated glycoprotein (MAG) are the major myelin proteins of peripheral nervous system (see for review, Morell et al., 1989). In addition, PMP-22 is integral membrane protein of the myelin in the peripheral nervous system (Suter et al., 1992). The mutation of PMP-22 gene was identified as a primary defect of autosomal dominant trembler mouse (Suter et al., 1992), which maps to mouse chromosome 11 (Davisson and Roderick, 1978). In the peripheral myelin disorders, Charcot-Marie-Tooth disease (CMT) 1A is autosomal dominant and linked to chromosome 17p11.2-p12 (MacAlpine et al., 1990).

Received July 6, 1992; Accepted August 10, 1992.

*To whom correspondence should be addressed. 
Genes in that region are conserved on mouse chromosome 11 (Münke and Francke, 1987). By analogy, PMP-22 could be a candidate gene for CMT 1A.

Recently, direct R-banding fluorescence in situ hybridization (FISH), which is based on FISH combined with replicated prometaphase $\mathrm{R}$-bands, has proved powerful for the precise localization of genes and DNA markers on the bands (Takahashi et al., 1990, 1991; Yamakawa et al., 1991). For the detection of single copy DNA markers with inserts of less than $5 \mathrm{~kb}$, an amplification procedure with goat antibiotin antibody and fluorescent antigoat IgG has been developed (ViegasPéquignot et al., 1989). Till now, this amplification procedure have been applied using a genomic clone containing a $2.1 \mathrm{~kb}$ insert and cDNA clone with a $0.5 \mathrm{~kb}$ insert (Takahashi et al., 1991; Lemieux et al., 1992).

We have cloned a full length of a cDNA of human PMP-22 (Hayasaka et al., 1992). In the present communication, we report a localization of PMP-22 gene by the combined FISH system.

\section{MATERIALS AND METHODS}

DNA probe. Isolation of the cDNA clone encoding PMP-22 has been previously reported (Hayasaka et al., 1992). A plasmid clone (J1h), which is a subclone of a $1.8 \mathrm{~kb}$ EcoRI fragment in pUC 19 derived from the lambda gt11 $\mathrm{Jlh}$ clone, was used as a DNA probe in the present study.

Direct R-banding FISH. The procedures of direct R-banding FISH have been described elsewhere (Takahashi et al., 1990). For the detection of the signals of PMP-22 probe, we applied the amplification procedures reported by ViegasPéquignot et al. (1989) with slight modification (Takahashi et al., 1991).

\section{RESULTS ANDịDISCUSSION}

We have examined 100 (pro)metaphase plates showing typical R-bands. Of them, $1 \%$ of such R-banded chromosomes exhibited complete double spots on both chromatids of both homologs, $20 \%$ were incomplete single and/or double spots on either or both homologs, and in the others (79\%) no spots were detectable. The fluorescent signals were localized to the R-positive pl1.2 band very close to R-negative p12 band of chromosome 17 (Fig. 1, a-d). No other double spots were observed. Thus, PMP-22 gene could be assigned to band 17p11.2. The CMT 1A has been localized to $17 \mathrm{p} 11.2-\mathrm{p} 12$ by genetic linkage and cytogenetic analyses (McAlpine et al., 1990; Patel et al., 1990; Vance et al., 1991; Lupski et al., 1991; Raeymaekers et al., 1991). The present result was within the map position of the CMT 1A gene by genetic linkage analysis, and strongly indicated that PMP-22 gene is a candidate gene for the CMT $1 \mathrm{~A}$.

As for the assignments of relevant genes, CMT 1B (1q21.1-q23.3), CMT X1 (Xq11-q13), CMT X2 (Xp22.2), and CMT X3 (Xq26) have been localized by genetic 

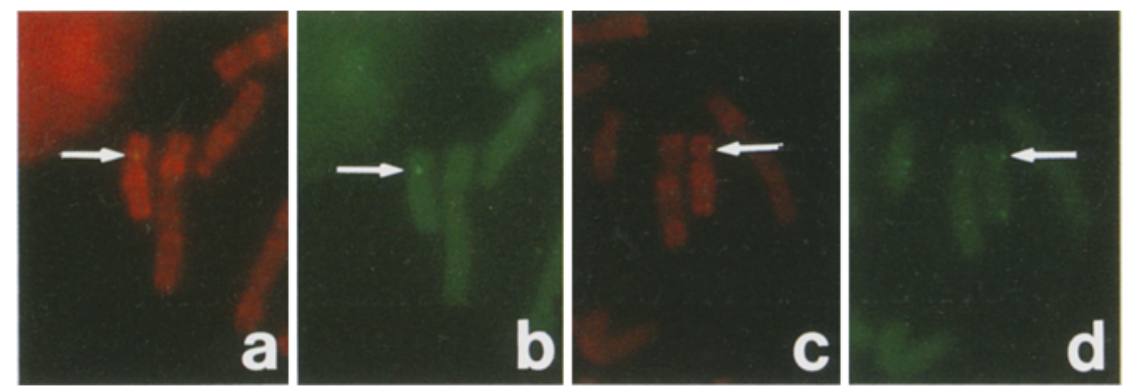

Fig. 1. Partial R-banded (pro)metaphases after FISH with biotinylated PMP-22 gene. Arrows indicate signals on $17 \mathrm{p} 11.2$. a and c, Nikon B-2A filter; $b$ and $d$, Nikon B-2E filter.

linkage analyses (see for review, Frézal and Schinzel, 1991).

It is worth noting that PMP-22 gene was located to R-positive $17 \mathrm{p} 11.2$ band. In mammals, early replicating $\mathrm{R}$-positive bands have been known to contain housekeeping genes, which are GC-rich in their DNA sequences (Holmquist et al., 1982; Goldman et al., 1984). Further work is being directed at examining the structure of genomic PMP-22 DNA sequences for this notion.

\section{REFERENCES}

Davisson MT, Roderick TH (1978): Status of the linkage maps of the mouse. Cytogenet Cell Genet 22: $552-557$

Frézal J, Schinzel A (1991): Report of the committee on clinical disorders, chromosome aberrations and uniparental disomy. Cytogenet Cell Genet 58: 986-1052

Goldman MA, Holmquist GP, Gray MC, Caston LA, Nag A (1984): Replication timing of genes and middle repetitive sequences. Science 234: 686-692

Hayasaka K, Himoro M, Nanao K, Sato W, Miura M, Uyemura K, Takahashi E, Takada G (1992): Isolation and sequence determination of CDNA encoding PMP-22 (PAS-II/SR13/GAS-3) of human peripheral myelin. Biochem Biophys Res Commun 186: 827-831

Holmquist G, Gray M, Ponter T, Jordan J (1982): Characterization of Giemsa dark- and lightband DNA. Cell $31: 121-129$

Lemieux N, Dutrillaux B, Viegas-Péquignot E (1992): A simple method for simultaneous R- or G-banding and fluorescence in situ hybridization of small single copy genes. Cytogenet Cell Genet 59: 311-312

Lupski JR, Montes de Oca-Luna R, Slaugenhaupt S, Pentao L, Guzzetta V, Trask BJ, SaucedoCardenas O, Barker DF, Killian JM, Garcia CA (1991): DNA duplication associated with Charcot-Marie-Tooth disease type 1A. Cell 66: 219-232

McAlpine PJ, Feasby TE, Hahn AF, Komamicki L, James S, Guy C, Dixon M, Qayyum S, Wright J, Coopland G (1990): Localization of a locus for Charcot-Marie-Tooth neuropathy type 1a (CMT1A) to chromosome 17. Genomics 7: 408-415

Morell P, Quarles RH, Norton WT (1989): Formation, Structure, and Biochemistry of Myelin. In: Siegel GJ, Agranoff BW, Albers RW, Molinoff PB (eds). Basic Neurochemistry: Molecular, Cellular and Medical Aspects. Raven Press, New York, pp 109-136

Münke M, Francke U (1987): The physical map of Mus musculus chromosome 11 reveals evolutionary relationships with different syntenic groups of genes in Homo sapiens. J Molec Evol

Vol. 37, No. 4, 1992 
25: $134-140$

Patel PI, Franco B, Garcia C, Slaugenhaupt SA, Nakamura Y, Ledbetter DH, Chakravarti A, Lupski JR (1990): Genetic Mapping of autosomal dominant Charcot-Marie-Tooth disease in a large French-Acadian kindred: identification of new linked markers on chromosome 17. Am J Hum Genet 46: 801-809

Raeymaekers P, Timmerman V, Nelis E, De Jonghe P, Hoogendijk JE, Baas F, Barker DF, Martin JJ, de Visser M, Bolhuis PA (1991): Duplication in chromosome 17p.11.2 in Charcot-MarieTooth neuropathy type 1a (CMT1a). Neuromuscular Disorders 1: 93-97

Suter U, Welcher AA, Özcelik T, Snipes GJ, Kosaras B, Francke U, Billings-Gagliardi S, Sidman RL, Shooter EM (1992): Nature 356: 241-244

Takahashi E, Hori T, O'Connell P, Leppert M, White R (1990): R-banding and nonisotopic in situ hybridization: precise localization of human type II collagen gene (COL2A1). Hum Genet 86: 14-16

Takahashi E, Hori T, O'Connell P, Leppert M, White R (1991): Mapping of the MYC gene to band $8 \mathrm{q} 24.12-\mathrm{q} 24.13$ by R-banding and distal to fra (8)(q24.11), FRA8E, by fluorescence in situ hybridization. Cytogenet Cell Genet 57: 109-111

Vance JM, Barker D, Yamaoka LH, Stajich JM, Loprest L, Hung W-Y, Fischbeck K, Roses AD, Pericak-Vance MA (1991): Localization of Charcot-Marie-Tooth disease type 1a (CMT1A) to chromosome 17p11.2. Genomics 9: 623-628

Viegas-Péquignot E, Lin LZ, Dutrillaux B, Apiou F, Paulin D (1989): Assignment of human desmin gene to band $2 \mathrm{q} 35$ by nonradioactive in situ hybridization. Hum Genet 83: 33-36

Yamakawa K, Takahashi E, Saito H, Sato T, Oshimura M, Hori T, Nakamura Y (1991): Isolation and mapping of 75 new DNA markers on human chromosome 3. Genomics 9: 536-543 